of the erythrocyte population was cde/---. In our view this could also be due to monosomy.

There may be other causes of changes in the $R h$ groups besides straightforward loss of genetic information by chromosomal monosomy or deletion. This is particularly likely to apply in the haematological disorders. For example, Tovey et al. (1961) reported the case of a female patient with chronic myeloid leukaemia whose red cells showed alteration in the expression of both the $A B O$ and $R h$ groups. The $R h$ genotype of this patient was $c D E / c d e$, but at certain times her red cells were not agglutinated with anti-D and weakly agglutinated by anti-E; nevertheless, absorption tests showed that the antigens were still present. The authors suggested that the $\mathrm{D}$ and $\mathrm{E}$ antigens had been modified as a consequence of the leukaemic state.

We hope that by reporting this example of a population of cells apparently monosomic for $\mathrm{Rh}$ associated with chromosomally abnormal cell lines in the bone marrow we may encourage anyone who encounters a case with populations of cells of mixed $\mathrm{Rh}$ groups to persuade the donor to submit to a bone marrow aspiration.
We thank Dr. E. B. Robson for the plasma and red cell isozyme tests and Miss F. Hyde for help with the chromosome studies.

Requests for reprints should be sent to Dr. Sylvia D. Lawler, Department of Clinical Research, Institute of Cancer Research and Royal Marsden Hospital, London, S.W.3.

\section{References}

Jenkins, W. J., and Marsh, W. L. (1965). Transfusion (Philadelphia), 5, 6. Kay, H. E. M., Lawler, S. D., and Millard, R. E. (1966). British fournal of Haematology, 12, 507.

Lawler, S. D., Millard, R. E., and Kay, H. E. M. (1970). European fournal of Cancer, 6, 223.

Levan, A. (1964). Hereditas, Genetiskt Arkiv, 52, 89.

Mannoni, P. P., Bracq, C., Yvart, J., and Salmon, C. (1970). Nouvelle noni, P. P., Bracq, C., Yvart, J., and

Millard, R. E., Lawler, S. D., Kay, H. E. M., and Cameron, C. B. (1968). British fournal of Haematology, 14, 363

Race, R. R., and Sanger, R. (1968). Blood Groups in Man, 5th edn., p. 22. Oxford and Edinburgh, Blackwell Scientific.

Shatwell, H. S. (1967). M.Phil. Thesis University of London.

Tovey, G. H., Lockyer, J. W., and Tierney, R. B. H. (1961).Vox Sanguinis, 6,628 .

Vogt, E. (1960). Nordisk Medicin, 64, 1370.

Vogt, E. (1964). Nordisk Medicin, 71, 510.

\title{
Controlled Trial of Amitriptyline in General Practice
}

\author{
T. G. BLASHKI, ROBERT MOWBRAY, BRIAN DAVIES
}

British Medical fournal, 1971, 1, 133-138

\section{Summary}

A controlled double-blind trial of amitriptyline at two dosage levels (75 and $150 \mathrm{mg} /$ day), amylobarbitone $(150 \mathrm{mg} /$ day), and an inert substance for a period of four weeks was conducted on four matched groups of women attending their general practitioners and suffering from a depressive illness. Improvement at 7 and 28 days was noted on several measures of depression and anxiety in all treatment groups. Of these treatments amitriptyline $150 \mathrm{mg} /$ day was the most consistent in relieving depression and anxiety. Troublesome side effects were equally distributed among the four treatments.

\section{Introduction}

Studies in general practice have shown that depressive symptoms are a frequent and important problem (Fry, 1961; Watts, 1966; Shepherd et al., 1966). During the 32 months of a survey about 1 in 13 women in a practice in Surrey attended at least once on account of a depressive illness (Porter, 1970). Few of the patients who present to their general practitioner with depressive symptoms are referred to psychiatric outpatient clinics, and fewer still are admitted to hospital. Thus there are likely to be differences between general practice populations and hospital populations of depressives.

To date, two controlled trials of antidepressants have been reported from general practice (Porter, 1970; Rickels et al., 1970). In the British study (Porter, 1970) the finding was that imipramine was not superior to placebo; in the American

Department of Psychiatry, University of Melbourne, Royal Melbourne Hospital, Victoria 3050, Australia

T. G. BLASHKI, D.P.M., M.A.N.Z.C.P., Second Assistant

ROBERT MOWBRAY, PH.D., F.A.Ps.S. Reader in Medical Psychology BRIAN DAVIES, M.D., F.A.N.Z.C.P., Cato Professor of Psychiatry study (Rickels et al., 1970) amitriptyline was more effective than placebo. Most trials have been conducted on hospital populations and, in general, they have yielded conflicting results (Klerman and Cole, 1963; Leyburn, 1967). In a review of the conflicting reports on the efficacy of antidepressants (Davies, 1968) it was pointed out that psychiatric opinions about the value of these drugs range from the optimistic view that "antidepressant drugs have revolutionized the treatment of depressed patients" to the cynical attitude that "antidepressants are only complex placebos for doctors."

Notwithstanding the conflicting evidence for their efficacy, the prescribing of antidepressants has steadily increased to the extent that between 1964 and 1966 the cost of antidepressants to the National Health Service rose from £2.37 to £3.13 million (Lancet, 1967). As the bulk of these prescriptions were from general practitioners it would seem to be important to test the efficacy of antidepressants on depressed patients as they present in general practice.

The main practical problems that face the investigator in general practice are the establishment of an operational definition of "depression," the use of reliable measures of change, ensuring that patients included in the trial have taken the prescribed tablets, and the detection of side effects. In addition, different doses of the active drug should be studied and the drug should be given for a sufficient period of time.

Amitriptyline was selected because it is a frequently used antidepressant in general practice. A period of four weeks was chosen because of the reports that antidepressant effects may not be seen for three weeks. The aim was to use a practical but rigorous methodology to compare the value of amitriptyline at two dosage levels-the "general practice" level of $75 \mathrm{mg} /$ day and the "hospital level" of $150 \mathrm{mg} /$ day. To take into account the placebo effect, comparison with an inert substance was introduced, and other patients received amylobarbitone $150 \mathrm{mg} /$ day. The design required four matched groups of patients attending their family doctors for treatment of their depressive illnesses. Particular attention was paid to socioeconomic factors-a decision which was subsequently justified by the finding that these factors interacted significantly with treatment effects (Rickels et al., 1970). 
In general, the conventional methods of hospital drug trials can be used in general practice. The effects of patients' expectations and physicians' enthusiasm can be reduced by using double-blind conditions. Standard techniques of assessment can be applied as readily to general practice as to hospital patients. Bias due to socioeconomic factors can be overcome by selecting patients from a number of practices. In one important respect, however, the general practice trial was considered to differ from the hospital trial. Most hospital trials do not select patients until they have been in hospital for 7 to 10 days, and any patients who improve in this time are usually excluded from the trial. Such a waiting period would be clinically unreal in general practice, and it was decided that a practical trial had to start from the patient's first presentation.

\section{Patients and Methods}

The patients studied were attending 21 general practitioners in Melbourne over a six-month period. The practices were deliberately selected to conform to eight socioeconomic areas of the city that have been described (F. L. Jones, 1967). In view of the reported sex differences in incidence of depression (Porter, 1970) and in response to antidepressants (Hamilton, 1967) only females over 15 years were studied (mean age 37.7).

Rigorous clinical criteria for admission to the trial were established beforehand and were discussed in detail with each of the general practitioners involved. It was agreed that a patient should have a persistent lowered mood with depressive symptoms-sleep and appetite disturbances, loss of interest, and inability to concentrate-and that her mental state should show depression and anxiety. Other psychiatric syndromes-organic brain disorders, schizophrenia, epilepsy, alchoholism, and mental retardation-had to be absent. Further, no patient was admitted to the trial if she had had electric convulsion treatment in the previous three months or had received any antidepressant medication in the previous month.

Patients were selected by the general practitioner and were asked to return to the surgery on the following day to be seen for one hour by a psychiatrist (T.G.B.). The capsules were then given to the patient by her family doctor. Every effort was made to avoid biasing the circumstances of the trial away from those that would normally occur in the management of depressive illnesses in a general practice setting.

\section{MEASURES OF DEPRESSION AND ANXIETY}

In addition to the clinical examination a number of objective and subjective assessments were undertaken of depressive and anxiety symptoms.

The Hamilton (1960) rating scale for depression was completed by the psychiatrist. This scale covers 17 symptom groups, each of which is rated by the clinician from zero to two, or from zero to four. The sum of these ratings was used as a score for global severity of the illness.

The Zung (1965) rating scale, on which the patient is asked to rate himself on a number of symptoms of depression. The total score gives a measure of the severity of subjective depression, and was used here to complement the objective ratings.

A clinical rating of the severity of the depression was made by the psychiatrist on a zero to four scale.

The Taylor (1953) manifest anxiety scale is a true-false questionnaire, completed by the patient, containing a number of symptoms of anxiety, and is a well-established measure of the degree of anxiety experienced by the patient.

$A$ clinical rating of the severity of the anxiety symptoms was made by the psychiatrist on a zero to four scale.

A 23 item list of side effects was presented to the patient and she was asked to indicate any which she experienced.

These six measures were completed at the start of the trial (day 1) and after 7 and 28 days. At these times patients were seen in the general practitioner's surgery by the psychiatrist, who also made a full clinical psychiatric assessment on each occasion. To maintain the conditions as close as possible to those of general practice, the general practitioner continued to see the patient during the trial at his usual rate, about once a week.

\section{Treatments}

Amitriptyline (Laroxyl) 25 and $50 \mathrm{mg}$, amylobarbitone $50 \mathrm{mg}$, and an inert substance were all prepared in identical orange capsules. Riboflavine $2.5 \mathrm{mg}$ was added to each capsule so that at 7 and 28 days urine samples could be tested for riboflavine fluorescence (I. H. Jones, 1967) in order to detect patients who were not taking their capsules.

Every general practitioner was given a number of coded bottles each containing a four-week supply of capsules. When he admitted a patient to the trial he noted the patient's name against the code on the label and instructed her to take one capsule three times a day. The code was kept separately so that both the general practitioner and the psychiatrist were blind as regards the contents of the capsules received by any patient. When the general practitioner thought a hypnotic was needed, nitrazepam (Mogadon) was supplied (5-10 mg at night). No other drugs were prescribed during the period of the trial. General practitioners were provided with an "escape clause" so that any patient who, in their opinion, became worse or complained of severe side effects could be removed from the trial.

\section{Results}

During the six months 82 patients were admitted to the trial but two were excluded by the psychiatrist (on day 1) as being too ill for general-practitioner treatment, and two failed to attend for the first psychiatric interview. A further 17 failed to complete the trial ("non completers") and are discussed later. Of the 61 patients who completed the trial, it was found that 18 had received the inert capsules, 16 had received amylobarbitone $50 \mathrm{mg}$ three times a day, 13 had received amitriptyline $25 \mathrm{mg}$ three times a day, and 14 had received amitriptyline $50 \mathrm{mg}$ three times a day.

Analysis of data from the patients' records showed that no differences in composition occurred between any of the four treatment groups and the "non-completers" with regard to marital status, number of children, education, socioeconomic background, religion, and country of birth.

The differences in number in the treatment groups would appear to have arisen by chance, as no relationship was found between treatment allocated and failure to complete the trial. Of the 17 "non-completers" five were in fact in the inert group and four in each of the other treatment groups.

The mean scores and their standard deviations for each treatment group at the three assessments are shown in Table I.

\section{INITIAL RATINGS}

When Student's $t$ test was applied to the initial scores no significant differences were found between mean ages and between mean scores on all measures for the four treatment groups, except for the patients on amylobarbitone, who were rated as significantly lower on the Hamilton scale than the group on inert treatment $(r=2.1 ; P=0.05)$. With this exception, the groups were considered to be matched for age and 
severity of depression and anxiety at the beginning of the trial.

The initial mean Hamilton score for the group of 61 patients was 17.4 (S.D. 4.9), indicating that those patients were less depressed than a group of hospital patients (mean 26.4; S.D. 5.6) selected for electric convulsion treatment (Carroll et al., 1970). Their initial levels of anxiety (mean Taylor score of 29.5; S.D. 9.8) can be contrasted with a group of hospital patients diagnosed as suffering from primary anxiety (mean 34.8; S.D. 3.3) (Fielding et al., 1969).

\section{CHANGES IN EACH TREATMENT GROUP}

Changes in the measures during the course of the trial were examined for each treatment group. The significance levels of these changes from the initial values for 7 days and 28 days were ascertained by Student's $t$ test and are given in Table II. Over the 28 days of the trial all treatment groups showed a significant reduction in objective ratings of depression (Hamilton and depression ratings), and this change was pronounced in the first seven days. Subjective ratings of depression (Zung) were in the same direction, and at the end of the trial significant reductions had occurred in the groups on inert medication and on the two dosage levels of amitriptyline, but not on the group receiving amylobarbitone 150 $\mathrm{mg} /$ day.

Significant reductions in objective ratings occurred over the trial for all treatments except the inert. Amylobarbitone 150 $\mathrm{mg} /$ day and amitriptyline $150 \mathrm{mg} /$ day produced significant reductions at seven days. A significant reduction in subjectively rated anxiety (Taylor scale) occurred only in the amitriptyline $150 \mathrm{mg} /$ day group. Changes in scores are shown in the Chart.

\section{COMPARISONS BETWEEN TREATMENTS}

The levels of statistical significance for the comparisons between treatment at 7 and 28 days are shown in Table III.

At seven days on objective ratings of depression (Hamilton and clinical rating) the group on amitriptyline $150 \mathrm{mg} /$ day were significantly less depressed than the inert group and (on the Hamilton scale only) the amitriptyline $75 \mathrm{mg} /$ day treatment group. A significant difference in Hamilton scores between the amylobarbitone and placebo groups before starting treatment was still present at seven days. There were no significant differences between treatments on the subjective (Zung) ratings of depression. Clinical ratings of anxiety showed the amylobarbitone $150 \mathrm{mg} /$ day group to be less anxious than the group on inert capsules, but this difference did not show on the subjective (Taylor) scale.

At 28 days the amitriptyline $150 \mathrm{mg} /$ day group remained significantly less depressed than the inert group on both objective ratings of depression, but not on the Zung subjective rating. The amitriptyline $150 \mathrm{mg} /$ day group were, however, significantly less depressed on this scale when compared with the amylobarbitone $150 \mathrm{mg} /$ day group. Clinical objective ratings of anxiety showed the amitriptyline $150 \mathrm{mg} /$ day group to be significantly less anxious than the other three treatment groups, though this difference was not significant on the Taylor subjective rating of anxiety.

\section{Effect of Situational Factors}

In this group of patients some considerable influence on the course of the symptoms could have been exerted by nonspecific factors such as personal or domestic problems, and treatment effects could have been obscured by the patients' reactions to changes in such problems. At the initial interview

TABLE I-Scores (Mean and Standard Deviation) at Initial and Follow-up Assessments by Treatment Group

\begin{tabular}{|c|c|c|c|c|c|c|c|c|c|c|c|c|c|}
\hline & & & & & & & & & & & Initial & 7 Days & 28 Days \\
\hline $\begin{array}{llll}\text { Inert tablets. } & \ldots & \ldots & \ldots \\
\quad N=18 & & & \\
\text { Mean age } & 37 \cdot 3 & \text { (S.D.) } & (14 \cdot 0)\end{array}$ & $\begin{array}{l}\cdots \\
\cdots\end{array}$ & $\begin{array}{l}\cdots \\
\cdots\end{array}$ & $\begin{array}{l}. \\
\because \\
\therefore\end{array}$ & $\begin{array}{l}\cdots \\
\cdots\end{array}$ & $\begin{array}{l}\cdots \\
\cdots\end{array}$ & $\begin{array}{l}. \\
\because\end{array}$ & $\begin{array}{l}\cdots \\
\because\end{array}$ & $\begin{array}{l}\cdots \\
\cdots\end{array}$ & $\begin{array}{l}\cdots \\
\because\end{array}$ & $\begin{array}{l}\text { Hamilton } \\
\text { Depression rating } \\
\text { Zung } \\
\text { Taylor } \\
\text { Anxiety rating }\end{array}$ & $\begin{array}{rr}18.9 & (4 \cdot 8) \\
2.5 & (0.6) \\
54.3 & (9.9) \\
30.3 & (10 \cdot 2) \\
1.9 & (0.6)\end{array}$ & $\begin{array}{r}14.2(6.2) \\
1.7(0.9) \\
46.6(13.3) \\
28.7(11.4) \\
1.6(0.7)\end{array}$ & $\begin{aligned} 11.4 & (9.6) \\
1.4 & (1.3) \\
43.2 & (15.6) \\
25.4 & (10.6) \\
1.3 & (1.1)\end{aligned}$ \\
\hline $\begin{array}{l}\text { Amylobarbitone } 150 \mathrm{mg} / \text { day. } \\
\mathbb{N}=16 \\
\text { Mean age } 37 \cdot \mathrm{i} \text { (S.D.) (13.3) }\end{array}$ & $\begin{array}{l}\cdots \\
\cdots\end{array}$ & $\begin{array}{l}\cdots \\
\cdots\end{array}$ & $\begin{array}{l}\cdots \\
\cdots\end{array}$ & $\begin{array}{l}\cdots \\
\cdots\end{array}$ & $\begin{array}{l}\cdots \\
\cdots\end{array}$ & $\begin{array}{l}\cdots \\
\cdots\end{array}$ & $\begin{array}{l}\cdots \\
\cdots\end{array}$ & $\begin{array}{l}\cdots \\
\cdots\end{array}$ & $\begin{array}{l}. \\
\because\end{array}$ & $\begin{array}{ll}. & \text { Hamilton } \\
\cdots & \text { Depression rating } \\
\therefore & \text { Zung } \\
& \text { Taylor } \\
& \text { Anxiety rating }\end{array}$ & $\begin{array}{rr}15.4 & (9.9) \\
2.2 & (0.6) \\
49.9 & (9.4) \\
27.1 & (10.1) \\
1.8 & (0.8)\end{array}$ & $\begin{array}{rr}9 \cdot 0 & (6 \cdot 7) \\
1.3 & (0 \cdot 9) \\
44.6 & (12 \cdot 3) \\
22.4 & (12 \cdot 1) \\
1.0 & (0.9)\end{array}$ & $\begin{array}{rr}8.3 & (6.0) \\
1.1 & (0.9) \\
44.3 & (13.1) \\
23.6 & (13.4) \\
0.8 & (0.7)\end{array}$ \\
\hline $\begin{array}{l}\text { Amitriptyline } 75 \mathrm{mg} / \text { day. } \\
\mathrm{N}=13 \\
\text { Mean age } 37 \cdot \dot{2} \text { (S. } \ddot{\mathrm{D}} \text {.) }(12 . \ddot{6})\end{array}$ & $\begin{array}{l}\cdots \\
\cdots\end{array}$ & $\begin{array}{l}\cdots \\
\cdots\end{array}$ & $\begin{array}{l}\cdots \\
\cdots\end{array}$ & $\begin{array}{l}\cdots \\
\cdots\end{array}$ & $\begin{array}{l}\cdots \\
\cdots\end{array}$ & $\begin{array}{l}\cdots \\
\cdots\end{array}$ & $\begin{array}{l}\cdots \\
\cdots \\
\cdots\end{array}$ & $\begin{array}{l}\cdots \\
\cdots\end{array}$ & $\begin{array}{l}\cdots \\
\cdots\end{array}$ & $\begin{array}{ll}\ldots & \text { Hamilton } \\
\therefore & \text { Depression rating } \\
\cdots & \text { Zung } \\
& \text { Taylor } \\
& \text { Anxiety rating }\end{array}$ & $\begin{array}{rr}17 \cdot 5 & (5 \cdot 2) \\
2 \cdot 3 & (0.5) \\
51 \cdot 4 & (8 \cdot 4) \\
30 \cdot 3 & (10 \cdot 4) \\
1.8 & (0.7)\end{array}$ & $\begin{array}{rr}11.2 & (3.9) \\
1.4 & (0.9) \\
42.8 & (12.8) \\
27.1 & (12.7) \\
1.0 & (0.9)\end{array}$ & $\begin{aligned} 6.4 & (5.4) \\
1.1 & (0.9) \\
38.8 & (11.4) \\
22.6 & (11.9) \\
1.1 & (0.9)\end{aligned}$ \\
\hline $\begin{array}{l}\text { Amitriptyline } 150 \mathrm{mg} / \text { day. } \quad \ldots \\
\mathrm{N}=14 \\
\text { Mean age } 35.4 \text { (S.D.) (12.7) }\end{array}$ & $\begin{array}{l}\cdots \\
\cdots\end{array}$ & $\begin{array}{l}\cdots \\
\cdots\end{array}$ & $\begin{array}{l}\cdots \\
\cdots\end{array}$ & $\begin{array}{l}\cdots \\
\cdots\end{array}$ & $\begin{array}{l}\cdots \\
\cdots\end{array}$ & $\begin{array}{l}\cdots \\
\cdots\end{array}$ & $\begin{array}{l}\cdots \\
\cdots\end{array}$ & $\begin{array}{l}\cdots \\
\cdots\end{array}$ & $\begin{array}{l}\cdots \\
\cdots\end{array}$ & $\begin{array}{ll}\therefore & \text { Hamilton } \\
\therefore & \text { Depression rating } \\
\therefore & \text { Zung } \\
& \text { Taylor } \\
& \text { Anxiety rating }\end{array}$ & $\begin{aligned} 17.6 & (4.5) \\
2.6 & (0.5) \\
50.4 & (8.3) \\
30.5 & (7.9) \\
1.9 & (0.8)\end{aligned}$ & $\begin{array}{rr}7 \cdot 1 & (4 \cdot 7) \\
0.9 & (0 \cdot 9) \\
41.9 & (8 \cdot 9) \\
27.1 & (12 \cdot 7) \\
1.1 & (0.8)\end{array}$ & $\begin{array}{r}5.1 \\
0.5(4.9) \\
34.5(7.7) \\
22.6(11.9) \\
0.3(0.6)\end{array}$ \\
\hline
\end{tabular}

TABLE II-Significance Levels (by Student's t Test) of Differences between Initial Scorts and Scores at 7 and 28 Days by Treatment Groups

\begin{tabular}{|c|c|c|c|c|c|c|c|c|c|c|c|c|c|c|c|c|c|}
\hline & & & & & & & & \multicolumn{2}{|c|}{ Hamilton } & \multicolumn{2}{|c|}{ Depressio n Rating } & \multicolumn{2}{|c|}{ Zung } & \multicolumn{2}{|c|}{ Anxiety Rating } & \multicolumn{2}{|c|}{ Taylor } \\
\hline & & & & & & & & 7 & 28 & 7 & 28 & 7 & 28 & 7 & 28 & 7 & 28 \\
\hline $\begin{array}{l}\text { Inert medication } \\
\text { Amylobarbitone } 150 \mathrm{mg} / \text { day } \\
\text { Amitriptyline } 75 \mathrm{mg} / \mathrm{day} \\
\text { Amitriptyline } 150 \mathrm{mg} / \mathrm{day}\end{array}$ & $\begin{array}{l}\ldots \\
\because \\
\cdots\end{array}$ & $\begin{array}{l}\because \\
\because \\
\because\end{array}$ & $\begin{array}{l}\because \\
\cdots \\
\cdots\end{array}$ & $\begin{array}{l}. \\
\because \\
\because\end{array}$ & $\begin{array}{l}. \\
\because \\
\cdots\end{array}$ & $\begin{array}{l}\because \\
\cdots \\
\cdots\end{array}$ & $\begin{array}{l}\ldots \\
\cdots \\
\ldots\end{array}$ & $\begin{array}{l}0.02 \\
0.01 \\
0.01 \\
0.001\end{array}$ & $\begin{array}{l}0.01 \\
0.001 \\
0.001 \\
0.001\end{array}$ & $\begin{array}{l}0.01 \\
0.01 \\
0.01 \\
0.001\end{array}$ & $\begin{array}{l}0.01 \\
0.001 \\
0.001 \\
0.001\end{array}$ & $\begin{array}{l}\text { N.S. } \\
\text { N.S. } \\
\text { N.S. } \\
0.02\end{array}$ & $\begin{array}{l}0.05 \\
\text { N.S. } \\
0.01 \\
0.001\end{array}$ & $\begin{array}{l}\text { N.S. } \\
0.02 \\
\text { N.S. } \\
0.05\end{array}$ & $\begin{array}{l}\text { N.S. } \\
0.01 \\
0.05 \\
0.001\end{array}$ & $\begin{array}{l}\text { N.S. } \\
\text { N.S. } \\
\text { N.S. } \\
\text { N.S. }\end{array}$ & $\begin{array}{l}\text { N.S. } \\
\text { N.S. } \\
\text { N.S. }\end{array}$ \\
\hline
\end{tabular}

TABLE III-Significance Levels ( $t$ Test) of Differences Between Preparations 7 at 28 Days

\begin{tabular}{|c|c|c|c|c|c|c|c|c|c|c|c|c|c|c|c|c|}
\hline & & & & & & & \multicolumn{2}{|c|}{ Hamilton } & \multicolumn{2}{|c|}{ Depression Rating } & \multicolumn{2}{|c|}{ Zung } & \multicolumn{2}{|c|}{ Anxiety Rating } & \multicolumn{2}{|c|}{ Taylor } \\
\hline & & & & & & & 7 & 28 & 7 & 28 & 7 & 28 & 7 & 28 & 7 & 28 \\
\hline $\begin{array}{l}\text { Inert } v \text { amylobarbitone } \\
\text { Inert } v \text { amitriptyline } 75 \mathrm{mg} / \text { day } \\
\text { Inert } v \text { amitriptyline } 150 \mathrm{mg} / \mathrm{day} \\
\text { Amylobarbitone } v \text { amitriptyline } 75 \\
\text { Amylobarbitone } v \text { amitriptyline } 150 \\
\text { Amitriptyline } 75 \mathrm{mg} / \text { day } v \text { amitrip }\end{array}$ & $\begin{array}{l}\cdots \\
5 \mathrm{mg} / \mathrm{da} \\
50 \mathrm{mg} / \mathrm{d} \\
\text { ptyline } 1\end{array}$ & $\begin{array}{cc}\cdots & \cdots \\
\cdots & \cdots \\
\text { ay } & \cdots \\
\text { day } & \\
150 & \text { mg/day }\end{array}$ & $\begin{array}{l}\cdots \\
\cdots \\
\cdots \\
\cdots\end{array}$ & $\begin{array}{l}\cdots \\
\because \\
\cdots \\
\cdots\end{array}$ & $\begin{array}{l}\ldots \\
\cdots \\
\cdots \\
\cdots\end{array}$ & $\begin{array}{l}\because \\
\because \\
\because \\
\therefore \\
\therefore\end{array}$ & $\begin{array}{l}0.05 \\
\text { N.S. } \\
0.01 \\
\text { N.S. } \\
\text { N.S. } \\
0.05\end{array}$ & $\begin{array}{l}\text { N.S. } \\
\text { N.S. } \\
\text { 0.05 } \\
\text { N.S. } \\
\text { N.s. } \\
\text { N.S. }\end{array}$ & $\begin{array}{l}\text { N.S. } \\
\text { N.S. } \\
\text { 0.05 } \\
\text { N.S. } \\
\text { N.S. } \\
\text { N.S. }\end{array}$ & $\begin{array}{l}\text { N.S. } \\
\text { N.S. } \\
0.05 \\
\text { N.S. } \\
\text { N.S. } \\
\text { N.S. }\end{array}$ & $\begin{array}{l}\text { N.S. } \\
\text { N.S. } \\
\text { N.S. } \\
\text { N.S. } \\
\text { N.S. } \\
\text { N.S. }\end{array}$ & $\begin{array}{l}\text { N.S. } \\
\text { N.S. } \\
\text { N.S. } \\
\text { N.S. } \\
\text { 0.05 } \\
\text { N.S. }\end{array}$ & $\begin{array}{l}0.05 \\
\text { N.S. } \\
\text { N.S. } \\
\text { N.S. } \\
\text { N.s. } \\
\text { N.S. }\end{array}$ & $\begin{array}{l}\text { N.S. } \\
\text { N.S. } \\
0.05 \\
\text { N.S. } \\
0.05 \\
0.02\end{array}$ & $\begin{array}{l}\text { N.s. } \\
\text { N.s. } \\
\text { N.s. } \\
\text { N.s. } \\
\text { N.s. } \\
\text { N.s. }\end{array}$ & $\begin{array}{l}\text { N.S. } \\
\text { N.S. } \\
\text { N.S. } \\
\text { N.S. } \\
\text { N.S. } \\
\text { N.S. }\end{array}$ \\
\hline
\end{tabular}



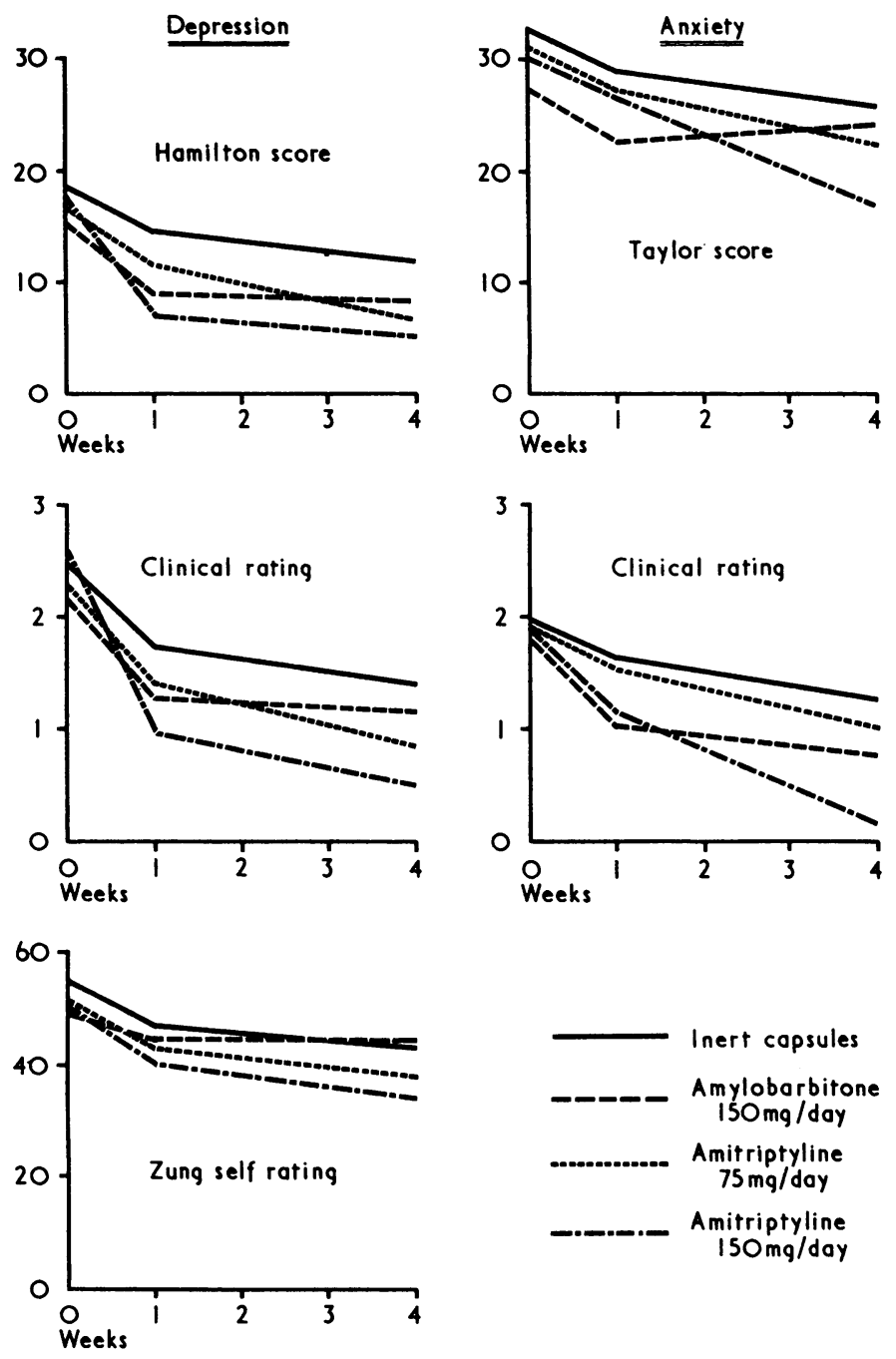

Changes in depression and anxiety scores.

the presence of such situational problems was noted and assessed clinically as "relevant" or "not relevant" to the clinical picture. At 7 and 28 days subsequent changes in the situation were noted. At the end of the trial 48 of the 61 patients were considered to have been subject to relevant situational factors. Testing by $\chi^{2}$ showed that no significant differences occurred between the four treatment groups in the number of patients in whom the situational factors were considered to be relevant or not, and in the number in whom the relevant situational factors were considered to have improved, remained the same or worsened.

Table IV relates the presence of relevant situational factors to the assessed outcome for the group as a whole at the end of the trial. No significant differences were found by $\chi^{2}$ between the numbers "improved" or "not improved" showing "relevant" or "not relevant" situational factors, nor in the numbers in whom the situational factors improved, remained the same, or worsened.

\section{SIDE EFFECTS}

Patients recorded their experiences of side effects on the prepared list of 23 items, with space provided for any unlisted symptoms. This method was more convenient than simply noting any spontaneously reported complaints, but it involved the risk of suggesting side effects to the patients. As all patients used these lists, no bias toward any treatment group could operate. This recording was done at the beginning of the trial as well as at the two follow-up interviews.
The findings in terms of the average number of side effects reported at the beginning of the trial are summarized in Table V. From this it is seen that a considerable number of symptoms were already present before the trial began. Some of these initial symptoms persisted during the trial (Table V). "True" side effects were taken to be those which emerged only in the course of treatment, and their average numbers are given in Table $\mathrm{V}$. No significant differences between the treatment groups were noted in the average numbers of side effects occurring during the trial. This analysis provides perspective and indicates the difficulty of identifying side effects of any drug.

The eight side effects which appeared most frequentlythat is, in more than four out of the total groups-are listed in Table VI in the manner in which they were presented to the patients. "Shakiness of legs or arms" and "blurred vision" were reported in all treatment groups. "Dry mouth" was more common with amitriptyline, but was also reported by two patients on amylobarbitone. "Fuzziness or unclearness in the head" was reported by all groups, except for amitriptyline $75 \mathrm{mg} /$ day. "Pains in the stomach" appear to be related to amitriptyline alone. Of the less frequent side effects (not listed) which could be attributed to amitriptyline, "swelling of the legs" was reported by three of the amitriptyline 75 $\mathrm{mg} /$ day group only, "incoordination of legs or arms" by two of the amitriptyline $150 \mathrm{mg} /$ day only, and "chest pain" by two of the amitriptyline $75 \mathrm{mg} /$ day only. In fact, no obvious differences were observed between the number and nature of side effects at the two dosage levels of amitriptyline. Somewhat unexpectedly, "constipation" was not reported with either of the two levels of amitriptyline-the two patients in the whole group who reported this were on amylobarbitone.

\section{"NON-COMPLETERS"}

Because they contributed a group comparable in size to the treatment groups it is important to consider in detail the 17 patients who failed to complete the trial. As mentioned previously, failure to complete was not related to the allocated treatment, and Table VII further shows that there

TABLE IV-Relationships between situational Factors and Outcome

\begin{tabular}{|c|c|c|c|c|c|c|c|c|}
\hline & & & & & \multicolumn{4}{|c|}{ Situational Factors } \\
\hline & & & & & \multirow{2}{*}{$\begin{array}{c}\text { Not } \\
\text { Relevant }\end{array}$} & \multicolumn{3}{|c|}{ Relevant } \\
\hline & & & & & & Better & Same & Worse \\
\hline $\begin{array}{l}\text { Improved } \\
\text { Not improved }\end{array}$ & $\because$ & $\because$ & $\because$ & $\because$ & $\begin{array}{l}7 \\
6\end{array}$ & $\begin{array}{l}3 \\
1\end{array}$ & $\begin{array}{r}27 \\
7\end{array}$ & $\begin{array}{l}7 \\
3\end{array}$ \\
\hline Total & $\ldots$ & $\ldots$ & . & $\ldots$ & 13 & 4 & 34 & 10 \\
\hline
\end{tabular}

TABLE V-Average Numbers of Side Effects Reported

\begin{tabular}{l|c|c|c|c}
\hline & \multirow{2}{*}{$\begin{array}{c}\text { Inert } \\
\text { Capsules }\end{array}$} & $\begin{array}{c}\text { Amylo- } \\
\text { barbitone } \\
150 \mathrm{mg} / \text { day }\end{array}$ & \multicolumn{2}{|c}{ Amitriptyline } \\
\cline { 4 - 5 } & & $75 \mathrm{mg} /$ day & $150 \mathrm{mg} /$ day \\
\hline Present initially & 5.5 & 6.1 & 6.9 & 6.9 \\
Eersisting during trial .. & 1.3 & $2 \cdot 1$ & 2.5 & 2.2 \\
Emerging during trial .. & 2.6 & 1.8 & 2.6 & 2.6 \\
\hline
\end{tabular}

TABLE VI-Frequency of Side Effects by Treatment

\begin{tabular}{|c|c|c|c|c|c|}
\hline \multirow{2}{*}{ Side Effect } & \multirow{2}{*}{$\begin{array}{c}\text { Inert } \\
\text { Capsules } \\
\mathrm{N}=18\end{array}$} & \multirow{2}{*}{$\begin{array}{c}\text { Amylo- } \\
\text { barbitone } \\
150 \text { mg/day } \\
\mathrm{N}=16\end{array}$} & \multicolumn{2}{|c|}{ Amitriptyline } & \multirow{2}{*}{$\begin{array}{l}\text { Whole } \\
\text { Group } \\
\mathrm{N}=61\end{array}$} \\
\hline & & & $\begin{array}{c}75 \mathrm{mg} / \text { day } \\
\mathrm{N}=13\end{array}$ & $\begin{array}{c}150 \mathrm{mg} / \text { day } \\
\mathrm{N}=14\end{array}$ & \\
\hline 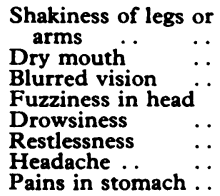 & $\begin{array}{l}\frac{4}{3} \\
4 \\
5 \\
3 \\
\end{array}$ & $\begin{array}{l}2 \\
2 \\
2 \\
3 \\
\\
5 \\
\end{array}$ & $\begin{array}{l}3 \\
5 \\
3 \\
\frac{3}{2} \\
\frac{1}{2}\end{array}$ & $\begin{array}{l}4 \\
6 \\
4 \\
5 \\
5 \\
\\
2\end{array}$ & $\begin{array}{r}13 \\
13 \\
12 \\
12 \\
10 \\
6 \\
5 \\
4\end{array}$ \\
\hline
\end{tabular}


TABLE VII-Characteristics of 17 Patients Who Did Not Complete the Trial

\begin{tabular}{|c|c|c|c|c|c|c|}
\hline \multirow{2}{*}{$\begin{array}{l}\text { Treatment } \\
\text { Allocated }\end{array}$} & \multirow{2}{*}{$\mathbf{N}$} & \multicolumn{2}{|c|}{ Initial Ratings } & \multicolumn{3}{|c|}{ Reasons for Not Completing } \\
\hline & & Hamilton & Taylor & $\begin{array}{c}\text { Side } \\
\text { Effects }\end{array}$ & $\begin{array}{c}\text { Depression } \\
\text { Worse }\end{array}$ & $\begin{array}{l}\text { Failed to } \\
\text { Attend }\end{array}$ \\
\hline $\begin{array}{l}\text { Placebo } \\
\text { Amylobarbitone }\end{array}$ & 5 & $17 \cdot 2(7 \cdot 1)$ & $27 \cdot 0(9 \cdot 9)$ & 4 & 0 & 1 \\
\hline $150 \mathrm{mg} / \mathrm{day}$. & 4 & $19 \cdot 25(6.9)$ & $28 \cdot 5(8 \cdot 3)$ & 0 & 3 & 1 \\
\hline $\begin{array}{c}75 \mathrm{mg} / \mathrm{day} \\
\text { Amitriptyline }\end{array}$ & 4 & $13.5 \quad(1.7)$ & $36 \cdot 3(4 \cdot 2)$ & 4 & 0 & 0 \\
\hline $\begin{array}{l}150 \mathrm{mg} / \mathrm{day} \\
\text { Whole group } . .\end{array}$ & $\begin{array}{r}4 \\
17\end{array}$ & $\begin{array}{ll}17.0 & (4.9) \\
16.9 & (5.8)\end{array}$ & $\begin{array}{l}34 \cdot 2(5 \cdot 2) \\
31 \cdot 2(7 \cdot 7)\end{array}$ & 11 & $\begin{array}{l}0 \\
3\end{array}$ & $\begin{array}{l}1 \\
3\end{array}$ \\
\hline
\end{tabular}

were no significant differences between the initial scores on the Hamilton and Taylor scales of this group and those of the 61 who completed the trial.

The 11 patients who failed to complete treatment because of side effects were distributed equally between the inert capsules and the two dosage levels of amitriptyline. For those on amitriptyline the two major reasons given were excessive drowsiness and a general slowing down of all activities. Nausea, drowsiness, dry mouth, and fuzziness of the head were reported by the patients on inert capsules. While none reported side effects three patients on amylobarbitone stopped taking the capsules because they felt they had become more depressed.

All of these 14 patients stopped taking the tablets within the first week of the trial. Twelve admitted spontaneously that they had stopped taking the capsules. The other two did not admit to having stopped, but urine tests showed no evidence of riboflavine fluorescence. These were the only cases in which failure to take the capsules was detected. All the 61 patients who completed the trial had positive tests for riboflavine in their urine at days 7 and 28.

\section{Discussion}

Multiple measures of change in the patients provided a wide coverage of both observer rating and self-assessment of depressive and anxiety features. There was an overall agreement in the trends yielded by these measures (see Chart), but there were obvious differences (see Tables II and III) in the degree to which the changes reached statistical significance. In general the observer ratings tended to be more likely to yield significance than the self-assessments. The problem then arises of whether to place more weight on the doctor's ratings and judgements or the patient's own assessment.

The rating scale method is relatively new and so far no specific information is available on the intercorrelations between these measures and their relative sensitivity to change. On general grounds, Hamilton (1960) argues that because the patient is inexperienced or unsophisticated in filling in inventories of this kind, the reliability of assessment methods is likely to be lower than the ratings of the experienced clinician. Rickels et al. (1970) emphasize the sensitivity of the Zung self-rating scale to population effects and its lack of sensitivity to drug effects when compared with objective ratings of depression. On these grounds the greater weight was placed on the objective measures.

As a group the patients who completed the trial all showed some improvement in their depression irrespective of which treatment was allocated. It is of interest to note that after 7 days $55 \%$, and at 28 days $61 \%$, of the patients on the inert substance were considered to have improved on clinical grounds. This represents a higher rate of improvement than occurs with inert tablets in psychiatric outpatients and inpatients (Rickels et al., 1970). Against this placebo response, only amitriptyline $150 \mathrm{mg} /$ day is capable of reflecting a consistent advantage on the objective measures and assessments of depression. This superiority appears at ane week and four weeks after treatment has begun.
The effects of amitriptyline $25 \mathrm{mg}$ three times a day, amylobarbitone, and inert capsules did not appear to be capable of being differentiated with any degree of consistency. Thus the effectiveness of amitriptyline would appear to be at the higher dosage levels preferred in hospital patients. Many general practitioners use tricyclic antidepressants at dosage levels of $75 \mathrm{mg} /$ day because they are concerned about possible side effects. This blind study indicates that there is no evidence that the effective dosage of $150 \mathrm{mg}$ of amitriptyline/ day either produces more side effects or causes more patients to stop their treatment because of side effects than $75 \mathrm{mg} /$ day.

In Porter's (1970) placebo-controlled study of imipramine in general practice the dosage of imipramine was changed from 75 to $150 \mathrm{mg} /$ day in the course of a three-week trial. No differences between imipramine and placebo were found, leading to the conclusion that depression in general practice may be effectively treated with support and a placebo. The findings of the present study would suggest that at the level of $150 \mathrm{mg} /$ day amitriptyline has effects over and above the placebo effect. Rickels et al. (1970) found that amitriptyline at a dosage of $100 \mathrm{mg} /$ day was superior to placebo over a fourweek period.

Comparative trials of imipramine and amitriptyline have produced conflicting results (Klerman and Cole, 1963). The different results which have been reported are most likely due to differences in the patients selected for the trials, to lack of uniformity in the dosage and length of administration of the antidepressants, as well as to differences in the methods used to assess changes in the patient's condition.

The effects of the medications on anxiety symptoms are of interest. All treatments, except the inert substance, produced a significant reduction in anxiety scores, which paralleled the reduction in depressive scores. After 28 days amitriptyline 150 $\mathrm{mg} /$ day was significantly better than the other treatments. Amylobarbitone was superior to the inert tablets at seven days in reducing anxiety scores, but this superiority did not persist to 28 days, when amylobarbitone, inert treatment, and amitriptyline $75 \mathrm{mg} /$ day could not be separated. The advantages of amitriptyline $150 \mathrm{mg}$ over amylobarbitone 150 $\mathrm{mg} /$ day could not be demonstrated to a statistically significant degree. This raises the question of whether "sedative" or "antidepressant properties" are being measured. In general the tendency was for amylobarbitone $150 \mathrm{mg} /$ day to achieve its improvement in the first seven days only, whereas improvement with amitriptyline $150 \mathrm{mg} /$ day continued over the period of the trial. This continued improvement may be consistent with so-called antidepressant effects. Analysis of the Hamilton ratings in terms of Hamilton's depression and anxiety factors, however, showed that while both amylobarbitone $150 \mathrm{mg} /$ day and amitriptyline $150 \mathrm{mg} /$ day produced improvement on these two factors, the improvement with amitriptyline was significantly greater. A more specific study would be required to test whether antidepressant and sedative effects could be separated and would require variation in the dosage of amylobarbitone administered.

The group of patients who did not complete the trial could not be identified on the basis of their background data or on the measures made at the beginning of the trial. The proportion of "non-completers" to those admitted to the trial agrees with that found in Porter's study (19/93). His finding, however, that 14 of these 19 were on the active drug, imipramine, was not confirmed in the present study, as neither the active treatment nor its dosage level affected the members who stopped taking their capsules. The size of this group is sufficient to justify further intensive study of these patients.

The practical conclusions from this trial of the effects of amitriptyline in a group of depressed women being treated in general practice are that: (1) a considerable placebo effect occurs, (2) no improvement over placebo was found with 75 $\mathrm{mg}$ of amitriptyline or $150 \mathrm{mg}$ of amylobarbitone/day, (3) 150 $\mathrm{mg}$ of amitriptyline/day was superior to placebo in relieving 
anxiety and depressive symptoms, and (4) depressed patients who stop medication complaining of side effects do not necessarily do so because these are pharmacologically induced.

We would thank the Research Committee of the Victorian Branch of the Australian College of General Practitioners for their co-operation and help. We would especially thank the individual general practitioners: Drs. D. Brodie, Blackburn South; D. Buchanan, Bulleen; T. Connors, Essendon; J. Downes, Toorak; J. Egan, Blackburn South; C. Gutch, Clifton Hill; L. Hartman, East Brunswick; D. Kaplan, Ashwood; G. Miles, Clifton Hill; M. Nissen, Windsor; K. Owen, Blackburn South; B. Phillips, Bulleen; J. Riddell, Balwyn; J. Sanders, Footscray; T. Springer, Melbourne; J. Starr, Ivanhoe; D. Stewart, Clifton Hill; H. Sutcliffe, Pascoe Vale; E. Thurin, Toorak; T. Wawryk, Pascoe Vale; R. Williams, Lower Templestowe. We also thank Miss Roslyn Sibbald for coordination of appointments between psychiatrist and patients. We are grateful to Dr. Richard Mulhearn, of Roche Products, for his help and for supplying the capsules.

\section{References}

Carroll, B. J., Mowbray, R. M., and Davies, B. (1970). Lancet, 1, 967. Davies, B. (1968). Australian and New Zealand fournal of Psychiatry, 2, 194. Fielding, J. M., Mowbray, R. M., and Davies, B. (1969). Medical fournal

of Australia, 2, 851.
Fry, J. (1961). Guy's Hospital Gazette, 75, 453.

Fry, (1961). Guy's Hospital Gazette, 75, 453. 23,56 .

Hamilton, M. (1967). In Drugs and the Mind, p. 80. Dunedin, University of Otago Press.

Jones, F. L. (1967). Australian and New Zealand fournal of Sociology, 3, 93.

Jones, I. H. (1967). Medical fournal of Australia, 1, 202.

Klerman, G. L., and Cole, J. O. (1963). Pharmacological Reviews, 17, 101. Lancet, 1967, 1, 1334.

Leyburn, P. (1967). Lancet, 2, 1135.

Porter, A. M. W. (1970). British Medical fournal, 1, 773.

Rickels, K., et al.(1970). Diseases of the Nervous System, 31, 30.

Shepherd, M., Cooper, B., Brown, A. C., and Kalton, G. (1966). Psychiatric Illness in General Practice. London, Oxford University Press.

Taylor, J. A. (1953). fournal of Abnormal and Social Psychology, 48, 285.

Watts, C. A. H. (1966). Depressive Disorders in the Community. Bristol, Wright.

Zung, W. W. K. (1965). Archives of General Psychiatry, 12, 63.

\title{
Y-Fluorescence of Interphase Nuclei, Especially Circulating Lymphocytes
}

\author{
P. E. POLANI, D. E. MUTTON
}

British Medical fournal, 1971, 1, 138-142

\begin{abstract}
Summary
Application of a fluorescence technique for the detection of the human $\mathbf{Y}$ chromosome in interphase nuclei indicates that the best results may be obtained from the study of lymphocytes in blood smears. The most satisfactory Y-fluorescence is obtained with the use of buffered quinacrine mustard dihydrochloride. The method can be complemented by other standard techniques to obtain a clear idea of the sexchromosome complement of the individual. The application of this technique to clinical and chromosomal diagnosis and to the prenatal detection of the $Y$ chromosome in amniotic cells seems at least as promising as has proved the earlier identification of the Barr body.
\end{abstract}

\section{Introduction}

The observation by Caspersson et al. (1968) of a specific fluorescent banding pattern in chromosomes of Vicia and other plants following treatment with the fluorochrome quinacrine mustard has generated interest in the application of this method to man (Caspersson et al., 1970a, 1970b; George, 1970a; Pearson et al., 1970). In human male metaphases the most prominent feature is a striking distal long-arm fluorescence of the $\mathrm{Y}$ chromosome (Fig. 1), which can also be observed in interphase nuclei and meiotic cells (Barlow and Vosa, 1970; Pearson and Bobrow, 1970). Work on interphase cells is particularly relevant to nuclear sexing in a variety of clinical states, but the method has been applied qualitatively and only to cultured cells and oral smears. For the technique to be proved suitable for both exact and rou-

Guy's Hospital Medical School, London S.E.1

P. E. POLANI, M.D., F.R.C.P., Professor of Paediatric Research D. E. MUTTON, B.sC. tine applications, the best and most easily accessible tissue must be identified, checks on reliability in normal and abnormal circumstances must be made, and the variability of results from technical and other sources must be assessed and quantification achieved. The present work explores the technique in relation to some of these objectives.

\section{Techniques}

After a pilot study we concentrated on the fluorescence induced by quinacrine mustard dihydrochloride (Q.M.) but quinacrine hydrochloride (Q) was also used. All solutions were freshly made up before use, but were found to remain active for at least a month when kept at $+4^{\circ} \mathrm{C}$. Q.M. (acridine, 9-[(4-[bis(2-chloroethyl)amino]-1-methylbutyl amino]-6-chloro-2-methoxy-,dihydrochloride) (see Loveless, 1970) was made up at a concentration of $250-300 \mu \mathrm{g} / \mathrm{ml}$ in $\mathrm{Mc}$ Ilvaine's buffer at $\mathrm{pH}$ 4.0-4.5. Slides were fixed in methanol for blood smears, methylated spirit ( $95 \%$ ethanol) for oral smears, and 3:1 ethanol-glacial-acetic for fibroblasts and amniotic cells, and the fixed slides were allowed to dry, washed in buffer for five minutes, stained in Q.M. solution for 15 minutes, rinsed in buffer, and mounted in buffer (George, 1970b). The coverslips were ringed with nail varnish.

$\mathrm{Q}$ (Atebrin) $0.5 \%$ was used either as aqueous solution (Q.A.) or in McIlvaine's buffer at $\mathrm{pH} 4.5$ (Q.B.). In the former case slides were washed in deionized water, stained for five minutes, washed in running tap-water for three minutes, and mounted on buffer at $\mathrm{pH} 5.5$ (Pearson et al. 1970). Conversely, Q.B. was applied for 15 minutes to slides washed in buffer at pH 4.5, which was also used to rinse and as a mountant. Preparations of cells from fresh amniotic fluid were made by spinning the fluid at 1,000 r.p.m. for five minutes, suspending the sediment in Hanks's balanced salt solution to wash, respinning as above, fixing and suspending the pelleted cells, resedimenting them, and taking them up in a small amount of fresh fixative to make air-dried preparations; direct smears from the sedimented cells, air-dried and fixed, were also satisfactory. 